\title{
Mouse Basal Cell Carcinoma
}

National Cancer Institute

\section{Source}

National Cancer Institute. Mouse Basal Cell Carcinoma. NCl Thesaurus. Code C134570.

Basal Cell carcinoma that occurs in a mouse. 